\title{
PRODUCTION OF TUNGSIEN-188 AND OSMIUM-194 IN A NUCLEAR REACTOR FOR NEW CLINICAL GENERATORS
}

\author{
S. Mircadeth. F. F. Knapp, Jr., and A. P. Callahan
}

\author{
Nuclcar Medicine Group \\ Health and Safety Research Division \\ Oak Ridge National Laboratory \\ Oak Ridge, TN 37831-6022
}

\begin{abstract}
DISCLAIMER
This report was prepared as an iscount of work sponsored by an agency of the United States Government. Neither the United States Government nor any agency thereof, nor any of their employees, makes any warranty, express or implied, or assumes any legal liability or responsibility for the accuracy, completeness, or usefulness of any information, apparatus, product, or process disclosed, or represents that its use would not infringe privately owned rights. Reference herein to any specific commercial product, process, or service by trade name, trademark. manufacturer, or otherwise does not necessarily constitute or imply its endorsement, recommendation, or favoring by the United States Government or any agency thereof. The views and opinions of authors expressed herein do not necessarily state or reflect those of the United States Government or any agency thereof.
\end{abstract}

Pesearch supported by the Office of Health and Environmental Research, U.S. Department of Energy, under contract DE-AC05-84OR21400 with Martin Marietta Energy Systems. Inc. 
Nuclear Medicine Gruup Hcalth and Safety Research Division

Oak Ridge National Laboratory

Oak Ridge, TN 37831-6022

\section{DISCLAIMER}

This report was prepared as an account of work spunsored by an agency of the United States Government. Neither the United States Government nor any agency thercol, nor any of their employees, makes any warranty, express or implied, or assumes any legal hiability or responsi. bility for the accuracy, completeress, or usefulness of any information, apparatus, product, or process disclosed, or represents that its use would not infringe privately owned rights. Reference herein to any specific commercial product, process, or service by trade name, trademark. manufacturer, or otherwise does nol necessarily constitute or imply its endorsement, recommendation, or favoring by the United States Government or any agency theroof. The views and opinions of authors expreased herein do not necesuarily state of refloct thoue of the 


\title{
ABSTRACT
}

\begin{abstract}
Rhenum-128 and iridium-194 are poceninal cinildates for radioimmunotherapy with monuclonal antibodies directed agairst tumor-associcated antigens. Both nuclei are short-lived and decay by high energy $B^{-}$emission. In addition, both nuclei emit $y$-rays with energy suitable for !maging. An important characteristic is availability of ${ }^{: 88} \mathrm{Re}$ and ${ }^{104} \mathrm{Ir}$ from decay of reactor-produced parents ( ${ }^{188} \mathrm{~W}$ and ${ }^{194}$ (is, respectively) in convenient generator systems. The ${ }^{188} \mathrm{~W}$ and ${ }^{194} \mathrm{Os}$ are produced by double neutron capture of ${ }^{186} \mathrm{~W}$ and ${ }^{192} \mathrm{Os}$, respectively. The large scale production yields of ${ }^{188} \mathrm{~W}$ in several nuclear reactors will be presented. We also report a new measurement for the cross-section of ${ }^{192} \mathrm{Os}\left(\mathrm{n}, y^{1}\right)^{144} \mathrm{Os}$ reaction and discuss the feasibility of producing sufficient quantities of ${ }^{195} \mathrm{Os}$.
\end{abstract}

h́cy words: Radionuclide Generator, ${ }^{188} \mathrm{~W} / /^{185} \mathrm{Re},{ }^{194} \mathrm{Os} /{ }^{194} \mathrm{Ir}$, Nuclear Reaction Cross-section, Nuclear Reactor

\section{INTRODUCTION}

We are currently developing the ${ }^{188} \mathrm{~W}\left(t_{i / 2}=70\right.$ d) $1^{188} \operatorname{Re}\left(t_{1 / 2}=17 \mathrm{~h}\right)^{1-6}$ and ${ }^{194} \mathrm{Os}\left(\mathrm{t}_{1 / 2}=6.0 \mathrm{y}\right) \mathrm{1}^{194} \mathrm{Ir}\left(\mathrm{t}_{1 / 2}=20\right.$ h) ${ }^{6.7}$ biomedical generator systems. The ${ }^{188} \operatorname{Re}$ and ${ }^{194}$ Ir daughters both decay by emission of high energy $B^{-}$

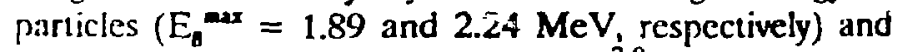
are potential candidates for therap $\%^{7-9}$ The decay of ${ }^{188} \mathrm{Re}$ Collows with emission of a predominant $155 \mathrm{KeV}$ $\gamma$-ray with moderate intensity $(15.8 \%)$ which can be efficiently detected with gamma cameras for in vivo biodistribution and kinetic studies. The decay of ${ }^{194} \mathrm{Ir}$ follows with emission of a $328 \mathrm{KeV} \gamma$-ray (13.0\%) which is also within the detection range of gamma cameras. In addition to the emission of an abundant high-energy particle, an appropriate physical half-life and stable daughter, both nuclei have suitable characteristics for protein labeling through bifunctional chelates. Rhenium-188 is of special interest since it is an analogue of $T c$ and recent advances in the chemistry of $T c$ for biomedical applications of ${ }^{99} \mathrm{Tc}$ could in principal be extended to Re.

The ${ }^{188} \mathrm{~W}$ and ${ }^{194}$ Os parent nuclei are produced in a fission nuclear reactor with double neutron capture on ${ }^{186} W$ and ${ }^{192}$ Os, respectively, according to the schemes shown in Figure 1a\&b. In the case of ${ }^{188} \mathrm{~W}$, we report here large scale production yield of ${ }^{188} \mathrm{~W}$ from ORNL HFIR, BNL-HFBR, MURR and FFTF reactors and compare the theoretical and experimental data. For ${ }^{194} \mathrm{Os}$ oroduction, the thermal neutron capture cross-section of rimary reaction, ${ }^{12} \operatorname{Os}(n, \gamma)$, is well known and is used extensively for neutron activation analysis of Os, however, he reported cross-section for the second reaction, ${ }^{3} \mathrm{Os}(\mathrm{n}, \gamma)$, differs significantly. ${ }^{10-14}$ An attempt has been nade to resolve this discrepancy and our results are resented in this report.

\section{EXPERIMENTAL}

Tungsten-188: Typically, $50 \mathrm{mg}$ of enriched ${ }^{186} \mathrm{~W}$ as $\mathrm{WO}_{3}$ (95\% enrichment) was encapsulated in a quartz ampule and irradiated for a period of 21 days (one reactor cycle) in the hydraulic (ube of the ORNL HFIR. Neutron fluxes and other irradiation conditions for various reactors are given in Table 1 . After irradiation, the target was generally allowed to decay for a perind of 10 days to reduce the ${ }^{187} \mathrm{~W}$ activity to a level comparable to that of ${ }^{188} \mathrm{~W}$ activity. Subsequently, the quartz ampule was crushed, $\mathrm{WO}_{3}$ was dissolved in $1.0 \mathrm{M} \mathrm{KOH}$ and a small aliquot $(-10 \mu \mathrm{L})$ was taken for assay.

Osmium-194: An ${ }^{192}$ Os target (27.1 mg with 99.3\% enrichment) encapsulated in a quart ampule was irradiated for one cycle (24 d) at position "Modified $\mathrm{V}-16^{*}$ together with 2.0 and $5.5 \mathrm{mg}$ of high purity Fe as llux monitors. The induced radioactivities in the ampules were measured directly without chemical separation. However, due to high levels of radioactivity, it was necessary to allow the samples to decay for a period of about 6 months before the first measurement.

Radioactivity Measurements: A calibrated $50-\mathrm{cm}^{3}$ high-purity Ge detector (EG\& G ORTEC, Oak Ridge, TN) coupled to a AccuSpec PC-based multichannel analyzer (Nuclear Data/Canberra Inc., Meriden, CT) was used for radioactivity measurements. The activity of ${ }^{187} \mathrm{~W}$ and ${ }^{188} \mathrm{~W}$ were quantitated by measurement of the intensity of their predominate $\gamma$-rays at $685.5 \mathrm{keV}$ (31.6\%) and $155.0(15.4 \%)^{14} \mathrm{keV}$ (from ${ }^{188} \mathrm{Re}$ daughter), respectively. For the determination of ${ }^{194} \mathrm{O}$, the 328.4 (13.0\%) keV g-ray (from ${ }^{194}$ Ir) was 


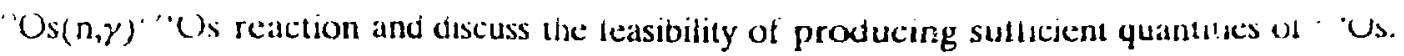

Key words $\quad$ Radionuclide Generntor, ${ }^{188} \mathrm{~W} /{ }^{184} \mathrm{Re}$, ${ }^{194} \mathrm{Os} /{ }^{194} \mathrm{Ir}$, Nuclear Reaction Cross-section, Niclear Reactor

\section{INTRCOTCTION}

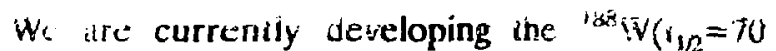

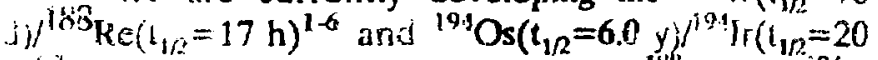

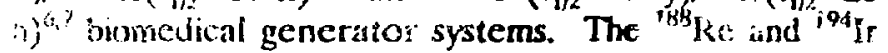
faughters both decay by emission of ingh anergy $B$ particles $\left(\mathrm{E}_{\mathrm{a}}{ }^{\text {nax }}=1.89\right.$ and $2.24 \mathrm{MeV}$, respectively) and we potentia! candidates for therapy. ${ }^{7.0}$ The decay of ' $\mathrm{N}$ Re follows with emission of a predommani $155 \mathrm{KeV}$ $\gamma$-ray with moderate intensity (15.8\%) which can be efficiently detected with gamma cameras for in vivo biodistribution and kinelic studies. The decry of ${ }^{194} \mathrm{Ir}$ follows with emission of a $328 \mathrm{KeV} \gamma$-ray (13.0\%) which s also within the detection range of gamma camcras. In Iddition to the emission of an abundant high-energy particle, in appropriate physical half-life and stable daughter. both nuclei have suitable characteristics for protein labeling through bifunctional chelates. Rnenium-188 is of spr. al interest since it is an analogue of $T c$ and recent advances in the chemistry of $T c$ for biomedical applications of ${ }^{900} \mathrm{Tc}$ could in principal be extended to Re.

The ${ }^{188} \mathrm{~W}$ and ${ }^{194}$ Os parent nuclei are prociuced in a fission nuclear reactor with double neutron capture on ${ }^{186} \mathrm{~W}$ and ${ }^{192} \mathrm{Os}$, respectively, according to the schemes shown in Figure 1a\&b. In the case of ${ }^{188} \mathrm{~W}$, we report here large scale production yield of ${ }^{188} \mathrm{~W}$ from ORNLHFIR, BNL-HFBR, MURR and FFTF reactors and compare the theoretical and experimental data. For ${ }^{194} \mathrm{Os}$ production, the thermal neutron capture cross-section of primary reaction, ${ }^{12} \mathrm{Os}(\mathrm{n}, \gamma)$, is well known and is used extensively for neutron activation analysis of Os, however, the reported cross-section for the second reaction, ${ }^{193} \mathrm{Os}(n, \gamma)$, differs significantly. ${ }^{10.14}$ An attempt has been made to resolve this discrepancy and our results are presented in this report.

\footnotetext{
Author lor correspondence

"HFIR: High Flux Isciope Reactor, Oak Ridge Nat. Lab. HFBR: High Flux Beam Reactor, Brookhaven Nat. Lab. MURR: Missouri University Research Reactor FFTF: Fast Fux Test Facility, Westinghouse Hanford Co.
}

\section{EXPERIMTNTAL}

Tungsten-188: Typically, $50 \mathrm{mg}$ on enriched ${ }^{186} \mathrm{~W}$ as $\mathrm{WO}_{3}$ (95\% enrichmeni) was encapsulated in a quartz ampule and irradiated for period of 21 days (one reactor cycle) in the hydraulic tube of the ORNLHFIR. Neutron fluxes and other irradiation conditions for various reactors are giver in Table 1 . After irradiation, the target was generally allowed to decay for a period of 10 days to reduce the ${ }^{187} \mathrm{~W}$ aclivity to a level comparable to that of ${ }^{188} \mathrm{~W}$ activity. Subsequently, the quartz ampuie was crushed, $\mathrm{WO}_{3}$ was dissolved in $1.0 \mathrm{M} \mathrm{KOH}^{s}$ and a small aliquot $(\sim 10 \mu L)$ was taken for assay.

Osmium-194: An ${ }^{192}$ Os target $(27.1 \mathrm{mg}$ with $99.3 \%$ enrichment) encapsulated in a quart ampule was irradiated for one cycle $(24 \mathrm{~d})$ at position "Modified $V-16^{*}$ together with 2.0 and $5.5 \mathrm{mg}$ of high purity $\mathrm{Fe}$ as flux monitors. The induced radioactivilies in the ampules were measured directly without chemical separation. However, due to high levels of radioactivity, it was necessary to allow the samples to decay for a period of about 6 months before the first measurement.

Radioactivity Measurements: A calibrated $50-\mathrm{cm}^{3}$ high-purity Ge detector (EG\&G ORTEC, Oak Ridge, TN) coupled to a AccuSpec PC-based multichannel analyzer (Nuclear Data/Canberra Inc., Meriden, $C$ ) was used for radioactivity measurements. The activity of ${ }^{187} \mathrm{~W}$ and ${ }^{288} \mathrm{~W}$ were quantitated by measurement of the intensity of their predominate $\gamma$-rays at $685.5 \mathrm{keV}$ (31.6\%) and $155.0(15.4 \%)^{14} \mathrm{keV}$ (from ${ }^{183} \mathrm{Re}$ daughter), respectively. For the determination of ${ }^{194} \mathrm{Os}$, the 328.4 (13.0\%) keV $\gamma$-ray (from ${ }^{294}{ }^{\mathrm{I}} \mathrm{r}$ ) was used. All other relevant ruclear data were taken from references 15 and 16.

\section{RESULTS AND DISCUSSION}

The experimental yields of ${ }^{188} W$ from four reactors (HFIR, HFBR, MURR, and FFTT) and 


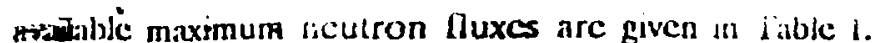
The large-scale production yicld of ${ }^{188} \mathrm{~W}$ at EOB from the HFIR hydraulic lube at $80 \mathrm{MW}$ power and for one cycle irradiation $(\sim 21 \mathrm{~d})$ at a thermal neutron flux of $2 \times 10^{15}$ $\mathrm{ns}^{\circ} \mathrm{cm}^{2}$ is a $\mathrm{mCi} / \mathrm{mg}$ of ${ }^{186} \mathrm{~W}$ which is lower than the theoreiral value by almost a factor of five. IIowcver, for a onc day imadiation at the HFBR the yicld , 189 , is lower thatn: the theoretical value by a factor of twe The extent of jiscrepancy between the theorctica! and expermenial values cannot be totally attributed ir. the neuireri sell-shiciding in the target matcriat since the effec was tound to be insiguificant in tic IIFDR expermencen in which two targets of 5 and $8 \mathrm{ing}$ were irradiated together and the induced activities of ${ }^{1833} \mathrm{~W}$ werc found to vary within $2 \%$ (Table 1). The higher yicle of ${ }^{189}$ W rom the HFDR versus HFIR, in spite of lower thermal neutron flux, is indicative of some contribution from resonance neutron absorptions in the epithermal region. The ncutron Rux spectrum is harder in the HFBR corc. The low yicld of $0.3 \mathrm{mCi} / \mathrm{mg}$ at MURR reliects the lower ncutron Mux. As indicated in Table 1, ihe yicld of ${ }^{187} \mathrm{~W}$ at $E O B$ is about 850 times higher than ${ }^{184} \mathrm{~W}$ for a 21-d irradiation in the HFIR.

Relative to the cross-scction of 1.28 mi lor ${ }^{58} \mathrm{Fc}(\mathrm{n}, \gamma){ }^{59} \mathrm{Fe}$ flux monitoring reaction, a cross-section of - $250 \mathrm{~b}$ was calculatcd for the ${ }^{193} \mathrm{Os}[\mathrm{n}, \gamma]^{194}$ Os reaction. A summary of the reported cross-section for this icaction is given in Table 2. Based on our data $12 \mathrm{mCi}$ of ${ }^{194} \mathrm{Os}$ can be produced by irradiating $25 \mathrm{mg}$ of enriched ${ }^{192} \mathrm{Os}$ for $60 \mathrm{~d}$ at HFIR $\left(\phi_{\mathrm{n}}=2 \times 10^{15} \mathrm{n} . \mathrm{cm}^{-2} \mathrm{~s}^{-1}\right)$ and the production of ${ }^{194} \mathrm{Os}$ at the HFIR is currently being explored.

\section{ACKNOWLEDGEMENTS}

Rescarch supported by the Office of IIcalth and Environmental Rescarch, U.S. Department of Encrgy, under contract DE-ACO5-84OR21400 with Martin Marictta Encrgy Systems, Inc. The authors thank Ms. L. S. Ailcy for secretarial assistance.

\section{REFERENCES}

1. Blachot J., IIcrmment J. and Moussa A., Appl.

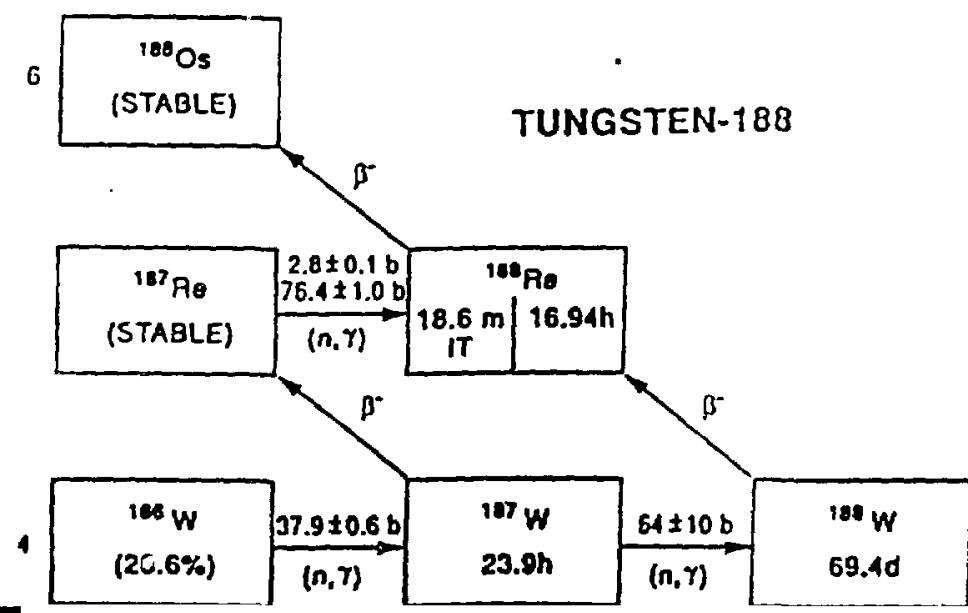

\section{Radiat. Isot., 20, 467 (1968).}

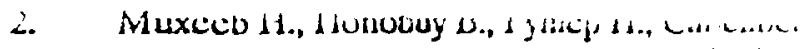
$\Gamma_{.}$Boakoba H., Isolopenpraxis, 8, 248 (1972).

3. Ehrhardi G., Ketring A. P., Turpin T. A., Razavi $M$. S., Vanderbeyden J.-L and Fritzberg A R., J. Nucl. Med 28, 656 (1987).

4. Callahan A. P., Ria: D. E anj Rnapp, F. F., Jr., NucCompact-Eus lamer Crmmin. Nucl. Med. 20, 3 (1989).

5. Kodina G., Tulskayă $r$ Cinteci t: Brodskaya G., Gapurova 0 . and Drosolovsky B., Production and Investigation of Rhenium-198 Generator, in Tochncium and Rhenium in Chemistre and Nuclcar Medicine 3 (M. Nicolini and G. Bandoli, edisors), Corina Intcrnational, (1990), pp 635-641.

6. Mani R. S., Radiochimica Acin, 41, 103 (1987).

7. Mirzadeh S., Callahan A. P., and Knapp, F. F., Jr., Iridium-194 - A New Candidate for Radioimmunothcrapy (RAIT) from an Osmium-194/Iridium-194 Generator System, 38th Annual Mecting of the Socicty of Nuclear Medicinc, Cincinnati. Ohio, Junc $11-14,1991, J$. Nucl. Med. (1991), in press.

8. Venkatcsan P. P., Shortkmft S., Zalutsky M. R., and Sledge C. B., Nucl. Med. Biol., 17, 357 (1990).

9. Grimiths G. L., Knapp F. F., Jr., Callahan A. P. Chang C.-H., Hansen H. J., and Goldenberg D. M., Cancer Rescarch, (1991) submitted.

10. Linder M., Phys. Rev., 84, 240 (1951).

11. Williams D. C. and Naumann R. A., Pliys. Rev., 134 B289 (1964).

12. Report BNL-325 3rd cl. (Mughabgab S. F. and Carber D. J.) Vol. 1, U.S. Government Printing OTTice, Washington D.C. (1973).

13. Casten R. F., Namenson A. I., Davidson W. F., Warner P. D. and Borner H. G., Physics Letters, 76B, 280 (1978). 
Tatile 1. Production of Tungsten-188

3Li:ictorj

irradation

rosition

Power Thermal
MW

Target mass. 8 as WO,

(Enrichmen! \%)
Yield mcilmg at EOB

Irradiation

Period
${ }^{187} \mathrm{~W}$

${ }^{188} \mathrm{YW}$
IIFIR-ORNL

IIT position \#

\#5

\#3

\#5

(1) $2.5 \times 10^{15}$

$\operatorname{l} x 1010^{15}$

$10.3,47.37$

$44.1 .96 .107)$

50.2 (4h.17)

$50.2(96.07)$

8) $2 \times 10^{15}$

$8 \times 10^{14}$

$60 \quad 8.25 \times 10^{14} 9.0 \times 10^{13}$

$$
4.97(97.06)
$$

$8.03(97.06)$

$5 \quad 4.5 \times 10^{14}$

$02.3(96.07)$

Flux Trap

FFTF-Hanford

$$
291
$$

$$
(1-2) \times 1 i^{1}
$$

$14.0(96.07)$

12.7 (96.07)

$21 \mathrm{~d}$

NM

4.49

3.94

$19.5 \mathrm{~d}$

NM

$3.25 \times 10^{5}$

3.88

$21.1 \mathrm{~d}$

$-40 d^{b} \quad N M$

6.22

8.8

NM

$2.62 \times 10^{-2}$

$24.0 \mathrm{~h}$

NM

$2.57 \times 10^{-2}$

$63.4 \mathrm{~d}$

$10 \mathrm{~d}^{\mathrm{s}}$

$10 \mathrm{~d}$
$3.89 \times 10^{-2}$

$3.81 \times 10^{-2}$

"Epithermal flux, ${ }^{\text {b) }}$ Several short and a $3-d$ shut down, "See reference 17

$E O B=$ End of Bombardment, $\mathrm{HT}=$ Hydraulic Tube, $\mathrm{NM}=$ not measured

Table 2 Thermal Ncutron Capture Cross-section of ${ }^{193} \mathrm{Os}$

Reactor/

Irradiation

position
Thermal Neutron Flux,

$\left(2200 \mathrm{~ms}^{-1}\right)$

$\mathrm{n} . \mathrm{s}^{-1} \mathrm{~cm}^{-2}$
Target mass, $\mathrm{g}$ as Os metal (Enrichment, \%)
Irradiation

Period
Efrective

\begin{tabular}{|c|c|c|c|c|c|}
\hline HFBR-BNL & $4.5 \times 10^{14}$ & $27.1(99.3)$ & $24 d$ & $240^{*}$ & this work \\
\hline ORNL-Graphite & $-1 \times 10^{12}$ & - & - & 200 & Lindner $(1951)^{10}$ \\
\hline MTR & $3 \times 10^{14}$ & 50 & $150 \mathrm{~d}$ & 8 & Williams $(1964)^{11}$ \\
\hline$?$ & $?$ & $?$ & $?$ & 1540 & Mughabghab $(1973)^{12}$ \\
\hline ILL/GAMS1-3 & $8 \times 10^{14}$ & $84(99.1)$ & on-line & $38 \pm 10$ & Casten $(1978)^{13}$ \\
\hline
\end{tabular}

Cross-section, References

b

'Measured

- Relative to the cross-section of $1.28 \mathrm{mb}$ for ${ }^{58} \mathrm{Fe}(\mathrm{n}, \gamma)^{59} \mathrm{Fe}$ Mux monitoring reaction

14. Coursey B. M., Calhoun J. M., Cessna J., Hoppes

16. Neutron Cross Sections, (Mughabghab, S. F., 


\#5 $\quad 80 \quad 2 \times 10^{12} \quad$ s $\times 10^{\circ} \quad 50.2(96.07) \quad$ an

HFHR BNL

V-14(care-edge)

$60 \quad 8.25 \times 10^{14} \quad 9.0 \times 10^{13}$

$4.97(97.06)$

$8.03(97.06)$

$24.0 \mathrm{~h}$

$24.0 \mathrm{~h}$

8.8

$2.62 \times 10^{-2}$

MURR

Thx Traf

$5 \quad 4.5 \times 10^{14}$

$721 \div 90.07)$

$63.4 d$

NMK

$2.57 \times 10^{-2}$

FFF Hind

291

(1.2) $\times 10^{14}$

$14.0(96.07)$

$2.7(96.07)$

$10 \mathrm{dj}^{\mathrm{s}}$

$3.89 \times 10^{-2}$

$10 \mathrm{~d}$

$3.81 \times 10^{-2}$

"Epithi'mai llux, "Several short and a 3-d shut down, See reference 17

$\mathrm{EOR}=$ End of Bombardment, $H T=$ Hydraulic Tube. $\mathrm{IVM}=$ not measured

Table 2 Thermal Ncutron Capture Cross-section of ${ }^{193} \mathrm{Os}$

\section{Reaciorl}

Irradiation

position
Thermal Neutron Flux,

$\left(2200 \mathrm{~ms}^{-1}\right)$

n.s.-1 $\mathrm{cm}^{-2}$
Target mass, g

as Os meinl

(Enrichment, \%)
Effective

Irradiation Cross-section, References

Period

\begin{tabular}{|c|c|c|c|c|c|}
\hline HFBR-BNL, & $4.5 \times 10^{14}$ & $27.1(k) .3)$ & $24 d$ & $240^{*}$ & this work \\
\hline ORNL-Graphite & $\sim 1 \times 10^{12}$ & - & - & 200 & Lindner $(1951)^{10}$ \\
\hline MTR & $3 \times 10^{14}$ & 50 & $150 \mathrm{~d}$ & 8 & Williams $(1964)^{11}$ \\
\hline$?$ & $?$ & $?$ & $?$ & 1540 & Mughabghab $(1973)^{12}$ \\
\hline ILL/GAMSI-3 & $8 \times 10^{14}$ & $8.1(99.1)$ & on-line & $38 \pm 10$ & Casten $(1978)^{13}$ \\
\hline
\end{tabular}

Measured

"Relative to the cross-section of $1.28 \mathrm{mb}$ for ${ }^{58} \mathrm{Fe}(\mathrm{n}, \gamma){ }^{59} \mathrm{Fe}$ flux monitoring reaction

14. Coursey B. M., Calhoun J. M., Cessna J., Hoppes D. D., Golas D. B., Schima F. J., Unterweger M. P., Callahan A. P., Mirzadeh S., and Knapp F. F., Jr., Radioactivity and Radiochemistry. 3, 38 (1990).

15. Table of Isotopes, (Lederer C. M. and Shirley V. S. Eds.), 7th ed, Wiley, New York (1978).
16. Neutron Cross Sections, (Mughabghab, S. F., Divadeenam $M$. and Holden N. E.), Vol. 1, part A\&B, Academic Press, (1981).

17. Schenter R. E. et al. (1990) and Report OSUNE-MED-9004 (Birney S. E. et al.), Analysis of ${ }^{188} W^{188}$ Re from MIP Test, (19)0). 